\title{
Niewidzialne obrazy. Fotografie uchodźców w dyskursie mediów
}

\section{Invisible images. Photographs of refugees in media discourse}

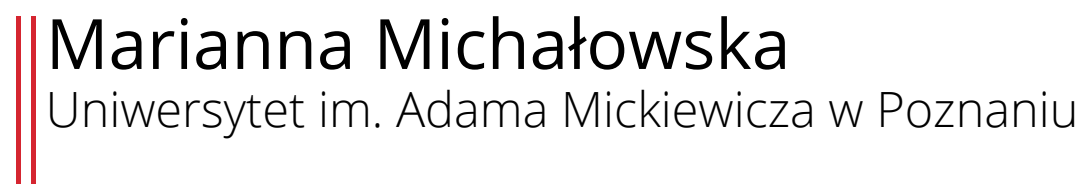

\begin{abstract}
The essay is devoted to the analysis of photographs of refugees published in contemporary digital media. I consider two seminal books: Regarding the Pain of Others by Susan Sontag (2003) and Civil Imagination. A Political Ontology of Image by Ariella Azoulay (2012) in regard to photographs by José Palazón and John Stanmeyer. Reflections by both writers are contradicted to concepts, among others, by W.J.T. Mitchell, Gillian Rose, Oliver Chanarin and Adam Broomberg. In regard to their thesis I argue that what we need nowadays is visual education, which develops the skill of critical interpretation of media messages. In the article I focus on the viewers' perspective, thus less attention is put to the photographers' intention. In the conclusion the interpretative approaches towards photography by Gillian Rose and Ariella Azoulay are presented.
\end{abstract}

Key words: photography, civil imagination, visual literacy.

Streszczenie: $W$ eseju przyglądam się publikowanym w sieci dwu fotografiom prezentującym obrazy uchodźców i uchodźczyń. Współczesne fotografie José Palazóna i Johna Stanmeyera zostają osadzone w kontekście przede wszystkim dwu kluczowych lektur - książki Regarding the Pain of Others Susan Sontag (2003) i Civil Imagination Arielli Azoulay (2012). Refleksję obu autorek zestawiam z koncepcjami m.in. W.J.T. Mitchella, Gillian Rose, Olivera Chanarina i Adama Broomberga. Z ich pomocą wskazuję na konieczność edukacji wizualnej, która rozwinie u odbiorcy umiejętność krytycznej interpretacji przekazów medialnych. W tekście zaprezentowana zostaje przede wszystkim perspektywa odbiorcza, dlatego też mniej uwagi poświęcam pracy fotoreportera wykonującego zdjęcie. W konkluzji przedstawiam propozycje podejść interpretacyjnych do fotografii: Gillian Rose i Arielli Azoulay.

Słowa kluczowe: fotografia, wyobraźnia obywatelska, alfabetyzm wizualny

Wydaje się, że każdy je widział: zdjęcie martwego dziecka wyrzuconego na brzeg morza, zdjęcie pola golfowego otoczonego siatką, na którą próbują wspiąć się ludzie, dziecka przekazywanego mężczyźnie przez zasieki drutu kolczastego. A jednak te zdjęcia są, jak będę starała się uzasadnić w tekście, niewidzialne. Spychane w podświadomość niewygodnego 
problemu, wykorzystywane jako argumenty $\mathrm{w}$ politycznych potyczkach. Niby widziane, lecz nie zobaczone. Żeby zobaczyć, musimy bowiem zrozumieć, co widzimy. Do tego zaś konieczny jest pewien rodzaj wyobraźni, w której zmieści się to, co przez nas postrzegane. Mój szkic został zainspirowany dwoma znakomitymi tekstami o fotografii: głośnym Regarding the Pain of the Others ${ }^{1}$ Susan Sontag z roku 2003 oraz nieco mniej znaną książką Arielli Azoulay Civil Imagination. W pierwszym z nich, napisanym niedługo po dyskusji o recepcji ataku na World Trade Center 11 września 2001, Sontag śledzi medialne przedstawienia wojen w XX wieku i dokonuje rewizji własnych tez z klasycznej książki O fotografii (1977), z kolei Azoulay proponuje refleksję opartą na obrazach konfliktu palestyńsko-izraelskiego. Zestawienie obu podejść krytycznych wymagało odwołania do innych, licznych tekstów o obrazach, dlatego też musiała pojawić się książka Czego chcq obrazy? W.J.T. Mitchella, rozważania Janiny Struk, refleksje Georges'a Didi-Hubermana czy pouczający z wielu względów (m.in. z uwagi na przedstawienie praktyki oceniania fotografii reporterskich w konkursach) esej fotografów/kuratorów wystaw Olivera Chanarina i Adama Broomberga Unconcerned but not Indifferent poświęcony dylematom towarzyszącym konkursowi World Press Photo. Obszar problemów podejmowanych w tekście jest ogromny, dlatego też dla przejrzystości wywodu zrezygnowałam $\mathrm{z}$ wprowadzenia relacji samych fotoreporterów ${ }^{2}$. Zainteresowanym polecam fascynujące, lecz trudne emocjonalnie książki Krzysztofa Millera (np. Fotografie, które nie zmieniły świata, 2017) czy Grega Marinovicha i João Silvy (Bractwo Bang Bang, 2012), kierując uwagę czytelnika ku - by użyć tu znanej kategoryzacji Rolanda Barthesa - perspektywie spectatora fotografii, nie zaś operatora (Barthes 1996).

Długo zastanawiałam się, na ile konieczne jest przywoływanie fotograficznych przedstawień uchodźców. Doszłam do wniosku, że moja teza o „niewidzialności” obrazów pozwala założyć, że obrazy te trwają w naszej podświadomości i ujawniają się mimowolnie (jak w koncepcji „pamięci mimowolnej" Prousta i Benjamina), toteż ich liczbę ograniczyłam do dwu zaledwie, modelowych w mojej opinii przykładów: fotografii José Palazóna i Johna Stanmeyera. Najważniejsze w tekście pozostaje, że obie autorki analizowanych tu książek, Azoulay i Sontag, opowiadają się za potrzebą przekroczenia granicy wizualności i potrzebą pogłębionej interpretacji obrazu. Można, co prawda, oskarżać Azoulay o naiwny idealizm, gdy

\footnotetext{
1 Polskie tłumaczenie tytułu zmienia nieco wydźwięk angielskiego tytułu. Tłumacz, Sławomir Magala, zaproponował jego brzmienie jako Widok cudzego cierpienia (Sontag 2010).

2 Wprowadzenie perspektywy fotografów kierowałoby nieuchronnie ku pytaniom o etykę fotoreportera, która nie jest zasadniczym tematem eseju. Co więcej, dyskurs ten niepotrzebnie „podkręca”, by tak powiedzieć, popkultura. Powraca za każdym razem, gdy dokumentację tragedii fotografowanych miesza się z biografiami twórców. Dotyczy to zarówno postaci Krzysztofa Millera czy Bractwa Bang Bang, czyli Kevina Cartera, Grega Marinovicha, João Silvy, Kena Oosterbroeka. Wątpliwości budzi przede wszystkim kulturowa mityzacja figury reportera w filmach popularnych, w których postaci fotoreporterów są redukowane do „myśliwych” polujących na dobry kadr. Zob. Bang Bang Club Stevena Silvera (2010), oparty na książce Marinovicha i Silvy, Gelhorn and Hemingway Philipa Kaufmana (2012), w którym pojawia się postać Roberta Capy. Najbliżej uchwycenia moralnych dylematów fotoreportera pozostaje Salvador Olivera Stone’a (1986).
} 
pisze o „społeczeństwie obywatelskim”, bo codzienna praktyka dowodzi, że postawa obywatelskości charakteryzuje mniejszość społeczeństwa. Jednak można także jej wezwanie potraktować jako rodzaj zadania dla tych, którzy prowadzą działania edukacyjne w obrębie mediów. Rozumiem zatem książkę Azoulay jako rodzaj wezwania skierowanego do osób zajmujących się obrazami profesjonalnie, dlatego też w konkluzji, przedstawiając wskazówki Azoulay o tym, jak interpretować fotografie, stawiam tezę o potrzebie edukacji medialnej, stanowiącej podstawę obywatelskiego społeczeństwa.

\section{Kontekstowość fotografii}

Zauważmy na wstępie, że spory o kulturowe i społeczne znaczenia fotografii toczą się od samego niemal początku istnienia fotografii. Czy fotografia jest nową dziedziną sztuki (jak chciała lady Elisabeth Eastlake w roku 1857)? Czy też służką nauk (jak chciał ją widzieć Charles Baudelaire dwa lata później)? Wiele z tych sporów dzisiaj straciło na aktualności, bowiem ważniejsze od dyskusji wokół pytania „czy fotografia jest sztuką?” staje się kwestia, jak obrazy wpływają na nasze myślenie o świecie oraz do jakich działań nas skłaniają? Już nie status estetyczny, ale stan poznawczy są ważne w sytuacji, gdy obraz fotograficzny stał się niewątpliwie głównym narzędziem komunikacji, źródłem wiedzy o świecie (Edwards 2014). Podstawowa oś sporu o fotografię dotyczy tego, czy fotografię traktować jako splot umiejętności i szczęśliwego zbiegu okoliczności („być we właściwym miejscu, we właściwym czasie"), czy też jako kulturową konstrukcję nie tylko zamierzoną przez fotografa, lecz także odczytywaną według społeczno-kulturowych kodów. Pierwsze podejście charakterystyczne jest dla tzw. „złotej ery fotoreportażu”. Jego podsumowanie znajdujemy w koncepcji „decydującego momentu” Henri Cartier-Bressona. Zgodnie z nim „reportaż jest wynikiem działania mózgu, oka i serca, pozwalającym na wyrażenie problemu, utrwaleniu wydarzenia i wrażeń" (Cartier-Bresson 1995, 2). Jeśli przeczytamy tekst Cartier-Bressona dalej, to zobaczymy, że także wielki fotograf był świadomy, że czasem końcowy efekt nie jest zapisem jedynie momentu, lecz "trwa godzinami a nawet dniami” (Cartier-Bresson 1995, 2). Ujęcie drugie znajdujemy w tekstach filozofów i badaczy kultury, m.in. Waltera Benjamina, Johna Bergera czy Allana Sekuli. Podkreślają oni, że mamy do czynienia z różnymi „użyciami” fotografii (Berger 1999). To znaczy, że chociaż obraz został zrealizowany według określonych intencji fotografa (który zresztą wykonał go w określonym celu, czyli kolejnym „użyciu”), to później podlega on rozmaitym interpretacjom tych, którzy go oglądają․ Pamiętajmy także, że oba podejścia różnicuje punkt widzenia

\footnotetext{
3 Terminem tym określa się epokę od lat 20. do 80. wieku XX, kiedy działali wielcy fotografowie reprezentujący m.in. agencje Magnum i Gamma. To czas Henri Cartier-Bressona, Roberta Capy, Georga Rogersa, Marca Riboud, Roberta Doisneau i wielu innych.

${ }^{4}$ Nie ma tu miejsca na przywołanie eksperymentu Jeana Mohra z napisanej wspólnie z Bergerem książki Another Way of Telling, w której fotograf (Mohr) badał, jak ta sama fotografia pozbawiona podpisu podlega różnym odczytaniom widzów (Berger, Mohr 1982).
} 
- perspektywa Cartier-Bressona reprezentuje spojrzenie fotografa wykonującego zdjęcie, w którym jak najlepiej powinna być przedstawiona intencja autora. Z kolei spojrzenia Bergera i Sekuli należą do interpretatorów, którzy mają przed sobą gotowy obraz i muszą zrekonstruować zarówno intencje fotografów, jak i kontekst przedstawionego zdarzenia (w tekście interesuje mnie przede wszystkim perspektywa druga - jak patrzymy na zdjęcia, a nie jak powinniśmy je robić).

Berger, uwzględniając wieloznaczność fotografii i liczbę możliwych skojarzeń z przedmiotami odniesienia, konstruuje zatem model „radialnego działania obrazu", które kładzie nacisk na kontekstowość interpretacji (Berger 1999, 87), zaś Sekula wskazuje na dwa bieguny społecznej interpretacji obrazu: symbolistyczny i realistyczny. Pomiędzy nimi wędrują użycia, by wymienić tylko kilka, informatywne (dziennikarskie, ale też naukowe), estetyczne (artystyczne) czy spirytualistyczne (charakteryzujące wiare $\mathrm{w}$ nadprzyrodzony charakter obrazu) (Sekula 2010, 21). Wymieszanie sposobów wykorzystania fotografii może prowadzić do nieporozumień - artystyczny fotomontaż podany jako źródło informacji wprowadza widza w błąd, podobnie jak estetyczna interpretacja fotografii pokazującej ludzkie cierpienia (walory kompozycyjne są ważne, lecz nie powinny przesądzać o znaczeniu takiej fotografii). Kontekst fotografii zostaje zmieniony także za sprawą miejsca prezentacji obrazu. Fotografia Capy przedstawiająca upadającego żołnierza republikańskiego w Hiszpanii, opublikowana w magazynie „Life”, inaczej była interpretowana w roku 1938, a inaczej ją odbieramy dzisiaj, oglądając w galerii sztuki.

Charakterystyczne dla fotografii są nie tylko „użycia”, współcześnie musimy brać pod uwagę także kulturową konwergencję mediów (Jenkins 2006, Kopecka-Piech 2015), czyli przenoszenia obrazu między medialnymi platformami (co prawda autorzy analizują głównie media elektroniczne, lecz obszar przemieszczeń można poszerzyć, włączając do nich nie tylko portale informacyjne, prywatne blogi, ale także pracę drukowaną czy nawet fizyczne przestrzenie miast). Co więcej, charakter danej platformy (portal poświęcony sztuce czy okładka prasy bulwarowej) i każda z przestrzeni fizycznych (muzeum, galeria sztuki, billboard), w których oglądamy zdjęcie, wpływa na sposób jej odbioru. Można zatem powiedzieć za Stuartem Hallem, że znaczenia reprezentacji (czyli wizualnych i językowych przedstawień) podlegają cyrkulacji w obiegu kultury, wędrując między procesami produkcji, dystrybucji i konsumpcji obrazów (Hall 1988, 1). To wstępne określenie proponowanego w szkicu rozumienia fotografii będzie szczególnie przydatne $\mathrm{w}$ analizie fotografii, których wykonaniu nie tylko sprzyjał zamiar fotografa, ale które następnie zaprezentowano oraz zinterpretowano w określony sposób. 


\section{Obraz i rozumienie}

Zdania w rodzaju „zdjęcia zmieniające świat” (Rostkowska 2015) brzmią dobrze. Jednak $\mathrm{w}$ istocie są one jedynie wyrazem naszej wiary w zdolność obrazu do zmiany świata, nadziei w większości nieuzasadnionej. Nie twierdzę, że obrazy nie apelują. Wręcz przeciwnie, od czasów Retoryki obrazu Rolanda Barthes'a (1964) po Czego chca obrazy? Williama J.T. Mitchella (2005) wiemy, że fotografie są komunikatami, silnie oddziałującymi na emocje odbiorców i skłaniającymi ich do podejmowania działań. Jednak to nie znaczy, że zmieniają świat. Wiedzą o tym wszyscy, którzy fotografią się zajmują: fotoreportażyści (jak wspomniany wcześniej Miller) i dokumentaliści działający na niwie sztuki. Tymi ostatnimi są Oliver Chanarin i Adam Broomberg, którzy początkowo zajmowali się fotoreportażem w RPA, by następnie działać jako kuratorzy wystaw i artyści wizualni. W 2008 roku zaproszono ich do jury World Press Photo. Wrażenia z tej pracy opisali $\mathrm{w}$ eseju. W jednym $\mathrm{z}$ jego fragmentów przekonują (za Wimem Wendersem), że decyzja o tym, jak nakierowuje się spojrzenie odbiorców na wydarzenie, jest polityczna - zależna od kontekstu kulturowego, ale także od hierarchii aktualnych wiadomości relacjonowanych w mediach ${ }^{5}$ (Broomberg, Chanarin, 2008). Obraz jest narzędziem w rękach nie tylko fotografów, lecz przede wszystkim edytorów, jurorów konkursów (dodać by należało - także wpływowych blogerów).

Sontag pisała gorzko w 2003 roku, że być może ostatnimi fotografiami, które doprowadziły do realnych działań politycznych, były opublikowane w amerykańskiej prasie fotografie z wojny w Wietnamie (Sontag 2003, 93), i to tylko dlatego, że trafiły na podatny grunt, na którym krytyczny wymiar fotografii zbiegł się ze społecznym krytycyzmem. Pewnie można by przekonywać, że takich ikonicznych fotografii było więcej - np.: fotografie z wojny w Bośni lub zdjęcie Lecha Wałęsy niesionego na rękach robotników po zakończeniu strajku ${ }^{6}$. To nie fotografie zmieniają świat, lecz czasem ich upowszechnienie przekonuje odbiorców do działań. Zwykle jednak, po pierwszym odruchu zainteresowania spectatora, znikają wśród innych, równie poruszających. Zmiana może nastąpić, gdy zrozumiemy to, co widzimy. Jednak trudno uczynić wysiłek rozumienia, gdy przed naszymi oczyma widzimy obraz cierpienia. O fotografiach pełnych bólu i przemocy mówi się, że szokują, że wykraczają poza naszą zdolność rozumienia i wyobrażenia. Taki charakter mają fotografie wojenne, tak też działają fotografie ukazujące skutki katastrof. „Nie jestem w stanie sobie tego wyobrazić” to częste, wypowiadane wobec nich stwierdzenie. Tymczasem fotografię

\footnotetext{
${ }^{5}$ Relacjonowane są wydarzenia uznawane przez wiodące media za „ważne”, a następnie są one powtarzane przez nadawców mniej wpływowych.

${ }^{6}$ O kłopotach z określeniem kanonu ikonicznych przedstawień i ich subiektywizacji pisały - na podstawie własnego projektu badawczego Fotoikony. Poszukiwanie/Głosowanie - Bogna Kietlińska i Joanna Kinowska. Autorki zaproponowały respondentom wytypowanie ważnych dla nich fotografii z XX wieku., następnie głosowano, które z tych obrazów są najbardziej rozpoznawalne. Okazało się, że wybór uwarunkowany jest emocjami, kompetencjami wizualnymi czy nawet geograficznym kontekstem widzów (Ziętkiewicz, Biernacka 2015).
} 
wykorzystywano po to właśnie, by uwidocznić, a tym samym dostarczyć dowodu na to, co niewyobrażalne. Tak zresztą rolę dokumentacji szczególnie drastycznych wydarzeń uzasadnia Georges Didi-Huberman. „Trzeba było nadać kształt niewyobrażalnemu", pisze w Obrazach mimo wszystko (Didi-Huberman 2008, 18). Ta dowodowa funkcja fotografii dokumentalnej i reporterskiej się nie zmieniła ${ }^{7}$ - pokazać, by inni mogli uwierzyć, że to, co widzą, istnieje. Coraz częściej konieczne okazuje się postawienie pytań nie tylko o etykę fotografowania (tę wprowadzają już podręczniki etyki dla fotografów), lecz o etyką oglądania obrazów, które mogą szokować. Broomberg i Chanarin w swoim eseju proponowali strawestować słynne stwierdzenie Roberta Capy. Już nie „jeśli twoje zdjęcia nie są dostatecznie dobre, to znaczy, że nie byłeś wystarczająco blisko”, lecz „jeśli twoje zdjęcia nie są dostatecznie dobre, to znaczy, że nie przeczytałeś wystarczająco wiele" (Broomberg, Chanarin 2008). Jurorzy World Press Photo kładą tu nacisk na potrzebę rozumienia kontekstu przedstawienia, zarówno przez fotografa, jak i przez widzów. Tę kwestię w mediach informacyjnych znakomicie ilustruje problem fotografowanych konfliktów, cierpienia, bólu.

W tytułach artykułów prasowych (warto przypomnieć, że z reguły fotografowie nie mają wpływu na wybory edytorów obrazu) odnoszących się do fotografii wykorzystywane są słowa odwołujące się do emocji odbiorcy, sugerujące, że to, co zobaczymy za chwile, nas zaszokuje. Uchodźcy $w$ obiektywie. Poruszajace zdjęcia z 2015 roku (Cieniek 2015), Shocking images of drowned Syrian boy show tragic plight of refugees (Smith 2015). Pojawiają się w nich takie wyrazy jak: szokujące, tragiczny (Smith 2016), poruszające (Cieniek 2015). Te słowa mają przyciągnąć uwagę odbiorcy (kiedyś - zwiększyć nakład, dzisiaj podnieść słynną „klikalność”). Jednak jak ustosunkować się do samego obrazu, kiedy już skuszeni tytułem „klikniemy" na artykuł i pojawią się obrazy?

Fotografie uchodźców - analogicznie jak obrazy wojny (a zwłaszcza ludobójstw) - z reguły prezentowane są $\mathrm{w}$ podobnych działach informacyjnych (tak prasy drukowanej, jak portali internetowych), poświęconych prezentacji społecznych katastrof. Odbiór tych obrazów jest szczególnie trudny. Janina Struk podkreśla, że wobec pewnych obrazów odczuwamy rodzaj blokady odbiorczej. Pisze: „czasami makabryczny charakter fotografii nie pozwala ustosunkować się do niej racjonalnie bądź krytycznie. Łatwiej się przed nią cofnąć, niż stawić jej czoło" (Struk 2007, 22). Podobnie dzieje się, gdy oglądamy katastrofę uchodźstwa. Badaczka podążą tu tropem myślenia Sontag. W Regarding the Pain of Others przedstawiony zostaje dylemat, z którym musi zmierzyć się odbiorca obrazów cierpienia.

\footnotetext{
${ }^{7}$ Odróżnienie fotografii dokumentalnej i reporterskiej przekracza możliwości skromnego eseju. Warto jednak zwrócić uwagę na płynność tych pojęć. Fotoreportaż odnosi się najczęściej do wymiaru informacyjnego, dostarczania informacji o tym, co dzieje się „teraz”, z kolei fotografia dokumentalna do ukazania dłuższego trwania (z reguły związanego z problemem społecznym). Jednak po czasie także fotoreportaż staje się dokumentem (Price 1996). W praktyce prasowej używany jest też termin fotodziennikarstwo (od ang. photojournalism) eksponujący narracyjny aspekt fotografii.
} 
Sontag porównywała przedstawienie ludzkiego bólu wykonane za pomocą dwu rodzajów technik: grafiki i fotografii. Grafika Goltziusa przedstawiała mężczyznę pożeranego przez smoka, fotografie były wykonywanymi w szpitalach portretami pacjentów, którzy ucierpieli w I wojnie światowej. Sontag pisze, że chociaż obrazy reprezentują równie dramatyczne sceny, to technika sprawia, że wobec fotografii nie można zastosować narzędzi poznawczych, które odwracałyby naszą uwagę od cierpienia (jak rozważanie techniki wykonania obrazu malarskiego lub grafiki). Fotografia zawsze stawia nas wobec przerażająco realistycznego okaleczenia żywego człowieka (Sontag 2003, 37). Szok wywoływany przez zdjęcia jest zatem konsekwencją tego, że fotografie uznajemy nie tylko za reprezentację rzeczywistości, ale że również przypisujemy im indeksalny ${ }^{8}$ charakter. Widzimy w nich rzeczywistość, która się zdarzyła (chociaż nie otrzymujemy odpowiedzi na pytania: jak i dlaczego?). Patrzenie na opisywane przez Sontag drastyczne fotografie prezentujące potworne zniekształcenia twarzy usprawiedliwić może jedynie medyczny kontekst (lekarz musi na nie patrzeć po to, by prowadzić terapię lub uczyć się, jak obrażenia takie leczyć). Oglądanie w innym celu jest perwersją. „Reszta z nas jest podglądaczami, bez względu na to, czy chce, czy nie chce nimi być" (Sontag 2003, 38). Znaczyłoby to, że oglądanie pewnych fotografii powinno być dopuszczalne jedynie w określonych sytuacjach (zapewne można by tu brać pod uwagę takie konteksty, jak sądowniczy, medyczny czy historyczny). Czy jednak wtedy z horyzontu społecznej świadomości nie zniknie wiedza o dokonywanej społecznie przemocy? Ariella Azoulay tego zaniku wiedzy się boi i stawia tezę odwrotną: wszystkie archiwa powinny być dostępne, bo blokowanie wiedzy jest mechanizmem dyscyplinowania jednostek. Nie pokazując, ukrywamy to, co się zdarzyło. Nie znaczy to, że Azoulay zachęca fotografów i odbiorców do łamania prawa fotografowanego do przeżywania cierpienia w samotności, wręcz przeciwnie - o czym piszę w dalszej części tekstu - zachęca do rozpoznania sensu tego cierpienia (Azoulay 2010).

Można by zadać pytanie, jak powyższe rozważania mają się do fotografii uchodźców? Rzecz w tym, że nie można oddzielać problemu uchodźstwa od zjawisk, które je spowodowały: wojny, katastrof naturalnych czy ogólnie - przemocy. W każdym z tych obszarów oglądamy cudze cierpienie i nie powinniśmy (zgodnie z tezą Sontag) tego cierpienia hierarchizować. Widok przemocy wywołuje określone reakcje. Fotografie są więc kłopotliwe (offensive), jak mógłby stwierdzić William J.T. Mitchell, wpływają na nasze zachowania, skłaniając także do aktów gwałtownych, takich jak zniszczenie, dewastacja lub usunięcie z pola widzenia (Mitchell 2005, 125-126). Sontag zauważa jednak, że przede wszystkim nie wiemy, jak się wobec obrazów cierpienia zachować, bo możemy być jedynie „spektatorami lub

${ }^{8}$ Termin z koncepcji semiotycznej Ch.S. Peirce'a, wykorzystywany w analizie fotografii dla określenia sposobu relacji znaku z przedmiotem fizycznym, która istnieje pomimo braku cech identycznych znaku z przedmiotem odniesienia (jak dym wskazujący ogień lub wskaźnik wiatru). 
tchórzami, niezdolnymi do patrzenia" (Sontag 2003, 38). Autorka Widoku cudzego cierpienia stawia nas więc $\mathrm{w}$ niewygodnej sytuacji, bo $\mathrm{w}$ żadnym z wyborów nie prezentujemy się w szczególnie pozytywnym świetle - ani voyeur, ani tchórz nie są sympatyczni - ale przynajmniej nadal zdolni jesteśmy do odczuwania. Pisarka przywołuje długą tradycję prezentacji męczeństwa i cierpienia w sztuce, polemizując jednocześnie $\mathrm{z}$ tezą, jakoby wielość obrazów okrucieństwa sprawiała, że stajemy się na nie odporni. Stwierdza: „wstrząsające fotografie niekoniecznie tracą swoją moc szokowania. Jednak nie pomagają w zadaniu rozumienia" (Sontag 2003, 80). Fotografowie zakładają, że fotografie cierpienia, szokując, przełamią obojętność i staną się przedmiotem refleksji, skłonią widza do działania. Tak jednak z reguły się nie dzieje (można by tu użyć porównania do opisanego przez Mieke Bal „efektu Meduzy”, czyli niezdolności do działania wobec obrazu przerażającego). Stojąc wobec obrazu pozbawionego komentarza, nie wiemy nic, potrzebujemy uzupełnienia i wyjaśnienia - potrzebujemy narracji. Sontag pisała: „Narracje mogą pomóc nam zrozumieć. Fotografie czynią co innego: nawiedzają nas" (Sontag 2003, 80). Do podobnych wniosków prowadzi doświadczenie jurorów Broomberga i Chanarina. Piszą, że na pierwszym etapie eliminacji oceniający jedynie oglądają projekcję zdjęć bez podpisów. Autorów to niepokoi, bo grozi dekontekstualizacją obrazu i w konsekwencji - błędnym odczytaniem znaczeń. Także oni podkreślają, że bez komentarza fotografia może wprowadzać w błąd (co w wypadku WPP często prowadzi do kontrowersji). Dlatego też uzupełnienie sfery wizualnej tekstem w odniesieniu do fotografii, która ma opowiadać o zdarzeniach, jest konieczne. Końcowy fragment eseju Sontag ma wydźwięk pesymistyczny. Autorka pisze:

nie mogę zrozumieć, nie mogę sobie wyobrazić. Oto, co każdy żołnierz, każdy dziennikarz, pracownik socjalny i niezależny obserwator, który został postawiony pod ogniem, i miał szczęście uniknąć śmierci, która uderzyła w innych tuż obok, uparcie czuje. I ma rację (Sontag 2003, 113).

Czy zatem, skoro fotografia nie jest w stanie przybliżyć nas do doświadczenia cierpienia, to jesteśmy skazani na niemoc? Wydaje się, że - by uwolnić się z tego moralnego znieruchomienia, niezdolności do osądu - musimy połączyć obraz z narracją i rozważyć, co właściwie widzimy. Do takiego podejścia zachęca izraelska badaczka obrazów, Ariella Azoulay.

\section{Zdarzenie fotografowania}

Zanim poddam analizie wymienione we wstępie fotografie José Palazóna i Johna Stanmeyera, przybliżę krótko pojęcia ważne dla koncepcji Azoulay. Badaczka obrazów posługuje się określeniami „polityczna wyobraźnia” i „obywatelska wyobraźnia”. O pierwszym autorka Civil imagination pisze, że jest „formą wyobraźni wychodzącą poza zasięg jednostkowego umysłu - jest formą wyobraźni, która wyrasta ponad jednostkę i istnieje pomiędzy 
jednostkami oraz jest przez nie dzielona" (Azoulay 2012, 5). Wyobraźnia polityczna dotyczy zatem wspólnych wartości i - co najważniejsze - przybiera konkretne formy, kształtujące ludzki sposób życia. Polityka dla Azoulay bliższa jest zatem myśleniu wspólnotowemu niż doraźnej działalności instytucji państwa. Jednak największym mankamentem politycznej wyobraźni w jej opinii jest to, że obejmuje tylko członków danej wspólnoty. „Polityczna wyobraźnia nie wystarcza, by wyobrazić sobie nie-obywateli lub obywateli drugiej klasy jako obywateli" (Azoulay 2012, 9). Polityczna wyobraźnia jest wykluczająca i dlatego konieczny jest drugi termin - „wyobraźnia obywatelska", dzięki któremu opowiedzieć się można za uznaniem za obywatela każdej istoty ludzkiej i przyznaniu jej równych praw. Nie bez powodu dla argumentacji badaczki ważne są koncepcje filozofów opowiadających się za wolnością - przedstawicieli myśli oświeceniowej - Woltera i Olympe de Gauges, frankfurtczyków: Adorna, Benjamina oraz Arendt i Ranciére'a. „Obywatelskość" dzisiaj, jak pisze Azoulay, powinna zostać uwolniona od powiązania z określonym systemem politycznym czy państwowym i zostać odniesiona do postawy świadomej jednostki. Obywatelska wyobraźnia, kontynuuje autorka, charakteryzuje tych, którzy rozumieją wizualne przekazy i umieją na fotografie spojrzeć w sposób krytyczny, by rozpoznać w obrazach relacje władzy. Obywatelskość zobowiązuje także, by opowiedzieć się po stronie słabszych. Można dostrzec w ideach Azoulay rodzaj naiwnego idealizmu, jednak jej rozważania o fotografii zwracają naszą uwagę na to, że można dzisiaj rządzić za pomocą obrazu. To posiadający władzę wyznaczają granice tego, co może zostać sfotografowane, a także tego, co może być pokazane publicznie (np. decydują o strefach, w których mogą pojawić się fotoreporterzy relacjonujący konflikty wojenne). Wydawałoby się, że pojawienie się Internetu i fotografii mobilnej tę władzę obaliło. Nie dajmy się jednak zwieść - do władz politycznych dołączyły nowe, dyktowane algorytmami globalnych wyszukiwarek i portali społecznościowych. Nie mam tu na myśli praktyk typowej cenzury, czyli zakazu publikowania określonych treści (o cenzurze towarzyszącej fotografii wojennej pisała też Sontag; Sontag 2003, 30). Dzisiaj zakazy są mniej widoczne - uwewnętrznione - lub nadzorowane wpisanymi w program regułami. Ich przestrzeganie wymuszane jest w sposób niemal niewidoczny.

Pojęcie obywatelskości posłuży nam do zrozumienia przekazu jednej z często ostatnio komentowanych fotografii. Najpierw sam obraz: zdjęcie pokazuje pole golfowe otoczone metalową siatką. Z zielenią fairwaya kontrastują figurki ubranych na biało golfistek (by być dokładną, muszę dodać, że jedna z nich ma ciemną koszulkę), w tle - na płocie zawisają ciemne postacie usiłujące przekroczyć granicę, po prawej stronie kadru widać drabinę i znajdującą się ponad nią umundurowaną postać ${ }^{9}$. Teraz do obrazu dodajmy kontekst: patrzymy na fotografię José Palazóna,

9 Zdjęcie dostępne na http://www.comillas.edu/en/chair-in-refugees/actuality/11011-jose-palazon-receives-the-human-rights-2016-award-in-communication (dostęp 17.10.2017). 
działającego w ramach - broniącej praw imigrantów - grupy PRODEIN ${ }^{10}$. Zdjęcie wykonano na granicy Maroka, w Melilli - hiszpańskiej enklawie w Afryce. Wizualna metafora jest jasna - zderzenie bogatego Pierwszego Świata ze światem wykluczonych. Jasny kolor pierwszego planu przeciwstawiony jest ciemnym figurom imigrantów. Czy jednak ze zdjęcia Palazóna dowiadujemy się, co dzieje się w Melilli? Jeden z komentatorów napisał, że pole powstało dzięki dotacji unijnej, której celem było zwiększanie atrakcyjności turystycznej rejonu i utworzenie nowych miejsc pracy (Czarnecki 2014). Jednak tego społeczno-politycznego konfliktu interesów, tego „coś za coś” zdjęcie nie pokaże. Nawet najbardziej przemyślana fotografia nie przekazuje bowiem jednoznacznego komunikatu, lecz - jak przekonywał Roland Barthes - oparta jest na kulturowych skojarzeniach ${ }^{11}$. Obraz rozpoznajemy, ponieważ formy i kolory odwołują się do naszych doświadczeń i wiedzy. Nasze myślenie o obrazie będzie odwoływało się także do naszych politycznych poglądów (o tym też pisała Sontag). Barthes przekonywał, że konotacje pojawiają się poza naszą świadomością (nazywał tę kategorię „trzecim przekazem” - po językowym i ikonicznym).

Fotografia Palazóna dla różnych grup ludzi będzie przywoływała odmienne treści. Dla zwolennika ruchu pro-imigranckiego fotografia będzie krytyką kapitalistycznej bezduszności, karmiący się strachem przed obcymi jego przeciwnik może czytać zdjęcie jako metaforę oblężenia cywilizacji przez barbarzyńców.

Spójrzmy na analizowaną fotografię w kontekście koncepcji Azoulay. Autorka proponuje rozróżnić w procesie fotografowania sfotografowane zdarzenie (photographed event) od zdarzenia fotografii (the event of photography). Pierwsze określenie odsyła nas do podejścia reprezentowanego przez takich fotoreporterów, jak Cartier-Bresson czy Capa. Fotograf dąży do tego, by w kadrze uchwycić zdarzenie. „Zarówno aparat jak i zdarzenie, które inicjuje [zdjęcie, M.M.] są, w dużej części, ograniczone okiem widza wprawionym w widzenie «rzeczy samej», czyli tego, czym się stanie sfotografowane zdarzenie" (Azoulay 2012, 21). Jesteśmy zatem wyszkoleni (kulturowo ukształtowani) w określonym sposobie patrzenia na fotografię. Postrzegamy ją jako przejrzyste okno, by zobaczyć samo zdarzenie ${ }^{12}$. Podobnie jak bohater Hitchcockowskiego Okna na podwórze widzimy tylko wycinek sytuacji i skazani jesteśmy na domysły co do znaczenia sceny. Z kolei fotograf obraca sfotografowanych ludzi i ich działania w obiekty. W podobny

\footnotetext{
${ }^{10}$ Organizacja PRODEIN (Asociación Pro Derechos de la Infancia) została powołana do pomocy dzieciom uchodźców mieszkającym w Melilli, hiszpańskiej enklawie w Maroku. Palazón jest jednym z jej założycieli. W 2016 roku otrzymał Nagrodę Praw Człowieka przyznawaną przez hiszpański Sąd Najwyższy. Nagrodę ufundowano dla tych, którzy „poświęcili życie pomocy najbardziej potrzebującym".

11 Z tezami Barthes'a dyskutują zorientowani neuropsychologicznie i kognitywistycznie tacy badacze, jak Chris Frith, którzy upatrują sposobu konstrukcji skojarzeń wizualnych w procesach mózgowych. W polskiej literaturze przedmiotu wyróżnia się oryginalna propozycja Piotra Francuza Imagia. W kierunku neurokognitywnej teorii obrazu (Francuz 2013).

12 Piszę tu o odbiorze potocznym. W badaniach nad fotografią koncepcja przezroczystości fotografii jest skutecznie podważana co najmniej od lat 60. XX wieku (zwłaszcza przez przedstawicieli kulturalizmu: R. Barthes'a, R. Krauss, H. Fostera, S. Halla, A. Sekulę, J. Tagga i wielu innych).
} 
sposób Sontag dostrzegała, że „fotografia obiektywizuje, obraca zdarzenie lub osobę w coś, co można posiąść" (Sontag 2003, 72). Takie uprzedmiotowienie budzi sprzeciw Azoulay. Niepokoi ją, że portretowani najczęściej nie mają wpływu na to, jak ich wizerunki zostaną wykorzystane (choć może się zdarzyć, że odnajdą swoje twarze w sieci i zaprotestują przeciw nadużyciom $^{13}$ ). Chodziłoby zatem o to, żeby przekaz fotografa, który uczony jest, by pokazywać zdarzenia „lepiej”, wydobywać „esencję” z rzeczywistości, zawierał „zwrócone spojrzenie” tego, kto przed obiektywem się znajduje.

Także Sontag pisała o zdarzeniu fotografii. Jednak traktowała je (zdarzenie) nieco inaczej i wskazywała na dwa możliwe procesy przekształcania zdarzenia w obraz - jednym było „upiększanie”, prowadzące do osłabienia moralnej odpowiedzi na to, co widzimy, drugim - „zbrzydzanie” (uglifying), które zmuszało do aktywnej odpowiedzi widza. Sontag zakładała, że doświadczenie brzydoty wywołuje szok. Zauważmy jednak, że po tym początkowym szoku pojawia się etap refleksji nad tym, co oglądaliśmy. Czy zdjęcie Palazóna „upiększa”, czy „zbrzydza”? Mamy tu do czynienia z sytuacja przewrotną, bo obraz niewątpliwie jest estetyczny - malowniczy pejzaż pola golfowego zdaje się sprawiać wrażenie, że zapominamy o problemie, ale jednocześnie to, co znajduje się w tle zdjęcia - obecność płotu i ludzi na nim zawieszonych - nas z tego spokoju wyrywa i prowokuje do zajęcia stanowiska wobec tego, co widzimy. Musimy się określić: po której stronie płotu jesteśmy? - tym samym - po której stronie sporu o uchodźców się opowiadamy?

A przecież portrety uchodźców jeszcze do niedawna (gdy problem migracji był bezpiecznie z punktu widzenia Europy sytuowany na jej peryferiach) należały do kanonu fotografii humanitarystycznej. Posługiwały się nimi organizacje społeczne (do dzisiaj czyni to UNICEF), by przekonywać o wartości pomagania najsłabszym. Co się zmieniło? Zobaczmy, porównując pracę Palazóna z obrazem innego znakomitego fotografa.

Autorem jednej z najgłośniejszych - wielokrotnie prezentowanych na wystawach i opublikowanych w licznych albumach - serii fotografii poświęconej migracjom jest Sebastiaõ Salgado ${ }^{14}$. Fotograf od lat 70. poświęcał swoje prace ludzkim tragediom. Pracując przez ponad sześć lat nad cyklem Exodus (2002), brazylijski fotograf przebył trzydzieści pięć krajów, by udokumentować codzienność migrantów zarobkowych, uciekających przed przemocą, głodem i wojną. Pokazał ludzi przekraczających granicę Meksyku i Stanów Zjednoczonych, Żydów opuszczających Rosję, Kosowian uciekających do Albanii, uchodźców Hutu w Rwandzie, głodujących w obozach dla

13 Tak było z fotografią Spencera Platta z roku 2006, przedstawiającą młodych Libańczyków wracających eleganckim kabrioletem do ruin domu w południowym Bejrucie. W jednym $\mathrm{z}$ artykułów prasowych autor zarzucił młodym ludziom, że żerują na ludzkiej tragedii. Bohaterowie zdjęcia zaprotestowali i starannie opisali własną sytuację; http://news.bbc.co.uk/2/hi/middle east/6385969. stm (dostęp 17.10.2017).

${ }_{14}$ Fotografie Salgado były wielokrotnie publikowane: Sahel: Man In Distress (1986); Other Americas (1986); An Uncertain Grace (1990); Workers (1993); Terra (1997); Migrations: Humanity in Transition (2000); The Children: Refugees and Migrants (2000); także w filmach - najniezwyklejszym jest Wima Wendersa The Salt of the Earth (2014). 
uchodźców w Etiopii czy pierwszych „boat people” płynących przez Morze Śródziemne. Ta przepiękna wizualnie, czarno-biała i jednocześnie przerażająca narracja stanowi argument, że krytykowane przez Sontag „upiększanie" może być narzędziem, które nie tyle zobojętnia na ludzką tragedię, ile może ją wydobyć ze społecznej obojętności. Tak przynajmniej swoje dążenie do ukazania piękna w tragedii uzasadniał sam Salgado.

John Berger, który współpracował z Timem Robbinsem przy filmie dokumentalnym poświęconym Salgado, mówił następująco: „Przyzwyczailiśmy się widzieć cierpiących ludzi tylko jako ofiary. Istnieje karmiony przez media syndrom katastrofy, promujący tylko sens współczucia. Tym, co próbuje zrobić [Salgado], jest pokazanie na fotografiach godności ludzi, nawet tych, którzy potwornie cierpią" (Wroe 2000). Chociaż wydawałoby się, że Salgado zainteresowany jest tylko dobrym kadrem, mistrzowsko skomponowanym, graficznie przetworzonym w czarno-biały obraz, to jego wizja innych przekracza ramy sfotografowanego zdarzenia - staje się metaforyczną narracją (jak mówią niektórzy - nawet romantyczną - Wroe 2000) o katastrofie wywołanej przez jednych ludzi, w wyniku której inni, ich bliźni, cierpią. Salgado był wielokrotnie krytykowany (Kimmelman 2001) zarówno za ów nadmiar piękna w kadrach, jak i ekskluzywne wydania albumów. Jednak należy zauważyć, że obecność Salgado w świecie sztuki od lat 90. ubiegłego wieku i prezentacja drastycznych tematów w wyrafinowanych galeriach miały swój sens. Wprowadzały tematy biedy, wykorzystywania, cierpienia do publicznej świadomości odbiorców. Czy takie podejście artysty - wiara w możliwość zmiany świata - było naiwne? Zapewne.

Humanitarny wydźwięk fotografii uchodźców zmienił się wraz z migracyjnym kryzysem ostatnich lat. Coraz częściej bohaterowie fotografii zostają uprzedmiotowieni, zmieniani w żywe argumenty polityczne, figury retoryczne mające potwierdzać stanowiska dyskutujących oponentów.

Wróćmy do omawianego wcześniej zdjęcia z Melilli. Palazón, budując kadr, ujawnił swoje stanowisko wobec prezentowanego problemu, nie posługując się zbliżeniem żadnego $\mathrm{z}$ bohaterów, nadał mu pozory obiektywności, jednak wybierając punkt widzenia, opowiedział się po stronie tych, którzy do „lepszego świata” uciekają. Możliwe są jednak odczytania odmienne. W obrazie dostrzec można krytykę zadowolonego z siebie konsumpcjonistycznego świata. Pole golfowe - dla wielu kulturowy symbol tzw. „problemów pierwszego świata” - może tej krytyce służyć.

Powróćmy teraz do drugiego z pojęć wprowadzonych w Civil Imagination. „Zdarzenie fotografowania” z reguły jest marginalizowane w dyskusjach o fotografii. Określenie to nie redukuje fotografii do kadru - oznacza działanie, różnorodną formę czasowości, serię spotkań i przede wszystkim uwzględnienie roli podmiotu. Zdarzenie fotografowania obejmuje nie tylko decyzję fotografa, w jakim kierunku zwrócić aparat, ale także uwzględnia miejsce fotografowanych podmiotów. Dzięki temu zdarzenie fotografowania zawiera także zdarzenia potencjalne (potential events), a więc takie, 
które ostatecznie nie znajdą swojej wizualnej reprezentacji (Azoulay 2012, 21-22). Sama obecność aparatu lub tylko możliwość jego obecności wpływa na zachowania uczestników zdarzenia fotografowania (chociaż nie zawsze są oni tego świadomi) i może być różnorako doświadczana: „irytująco, przyjemnie, zagrażająco, inwazyjnie, represyjnie, łagodząco czy nawet uspokajająco" (Azoulay 2012, 22). Tego wszystkiego nie pokazuje nam jednak fotografia z Melilli, chociaż może stać się dla widzów źródłem istotnych refleksji. Zdarzenie fotografowania obejmuje bowiem nie tylko to, co dzieje się między fotografem i fotografowanymi. Istotnymi uczestnikami tego wymiaru zdjęcia jesteśmy także my, widzowie.

\section{Niewidzialność obrazów}

Dyskurs medialny nie posługuje się jednak niuansami, do odkrycia których zachęca Azoulay. Za sprawą konwergentnego charakteru cyfrowych obrazów stają się one niezwykle podatne na dekontekstualizację i manipulację. Przeklejane pomiędzy stronami, dzielone z innymi w sieciach społecznościowych nie tylko są popularyzowane, ale także obrastają nowymi kontekstami. Zwykle są to takie obrazy, o jakich mówi komentarz do artykułu prasowego opisującego jedną z wystaw World Press Photo. „Najlepsze fotografie zeszłego roku pokazują tułaczkę uchodźców, wojny i protesty" (Petty 2016). Te obrazy zazwyczaj sięgają do kategorii emocjonalnych. Jeśli fotografie mają nas poruszać, to prezentowane są zdjęcia dzieci, jeśli wydawcy chcą oburzać - pokażą mężczyzn z bronią. Przy wykorzystywaniu obaw i sympatii oryginalny kontekst obrazu schodzi na dalszy plan.

Kiedy Broomberg i Chanarin oceniali zdjęcia w WPP, starali się wybierać takie fotografie, które są nieoczywiste. Reprezentowany przez nich nurt znajduje zwolenników. W 2014 roku pierwszą nagrodę w kategorii zdjęć pojedynczych zdobyło zdjęcie zatytułowane Sygnał Johna Stanmeyera ${ }^{15}$. Na fotografii widzimy stojące na brzegu morza, na tle ciemnobłękitnego nieba, niemal czarne ludzkie figury. Postacie unoszą w górę światełka. Towarzyszący zdjęciu opis jest następujący: „26 lutego 2013. Afrykańscy migranci na wybrzeżu Dżibuti nocą unoszą swoje telefony w poszukiwaniu zasięgu z pobliskiej Somalii - wątły związek z bliskimi za granicą. Dżibuti jest częstym punktem postoju dla migrantów przemieszczających się z krajów takich jak Somalia, Etiopia i Erytrea, poszukujących lepszego życia w Europie i na Bliskim Wschodzie".

$\mathrm{W}$ istocie, bez tego podpisu zdjęcie jest niejasne. Można by je odczytać jako dziwny performans na plaży lub kadr z filmu o spotkaniu z obcymi. Ponownie warto sięgnąć do opinii Broomberga i Chanarina obserwujących, że fotografie pokazywane na WPP bez podpisu są bezsilne (Broomberg, Chanarin 2008). Znaczyłoby to także, że fotografiami wyrwanymi z kontekstu bardzo łatwo manipulować. Podatność zdjęć na manipulację stanowi

${ }^{15}$ https://www.worldpressphoto.org/collection/photo/2014/contemporary-issues/john-stanmeyer 
ambiwalentną cechę medium. Przykładem pozytywnej strony takiej manipulacji niejednoznacznością może być fotografia Stanmeyera. By oddziaływać na widza i skłaniać go do refleksji, jej autor nie posługuje się efektem szokowania. Przykuwa naszą uwagę w inny sposób, intrygując niejednoznacznością i zachęcając do jej rozwikłania (jak zachęcają nas do tego szarady lub rebusy).

Negatywną stronę wieloznaczności obrazu zaprezentuję na przykładzie tego, jak współczesny dyskurs wobec uchodźców podporządkowuje fotografię doraźnym celom politycznym. Latem 2017 roku głośno było o nadużyciach wobec oryginalnych fotoreporterskich prac, wykorzystanych w fotomontażu opublikowanym na okładce "Gazety Polskiej”. Na okładce tygodnika umieszczono kompozycję przedstawiający mężczyzn i kobiety w afgańskich strojach pochylonych nad zwłokami przykrytymi białą tkaniną. Nad ich głowami grafik umieścił widok ciemnego nieba, które przecinają błyskawice. Napis głosi „Uchodźcy przenoszą śmiertelne choroby” ${ }^{16}$. Oczywiście można argumentować, że fotomontaż rządzi się innymi prawami niż oryginalna fotografia, jednak nie należy zapominać, że fotograficzne przedstawienie najczęściej traktowane jest przez odbiorców w sposób realistyczny. Co więcej, dziennikarstwo (także fotodziennikarstwo) ma znaczący wpływ na opinię publiczną. O tym właśnie pisze Azoulay w odniesieniu do obywatelskiej wyobraźni. Obywatelskość zakłada podjęcie odpowiedzialności za obrazy - zarówno w wymiarze odbiorczym, jak nadawczym. Tę odpowiedzialność podkreśla także Lesley Wischmann, zauważając - inaczej niż Azoulay - że czasem ta odpowiedzialność powinna powstrzymywać nadawców od prezentacji niektórych obrazów (Wischmann 1987, 69).

Kontrowersje wokół przywołanej okładki wywołało to, że obraz złożono ze zdjęć wykonanych w innym miejscu i innym kontekście, bez zgody fotografów. Agencja fotograficzna „Forum”, dla której pracują autorzy wykorzystanych w fotomontażu zdjęć - Rafał Wojczal i Wojciech Wilczyński - wydała następujące oświadczenie: „Jesteśmy oburzeni sposobem wykorzystania tych zdjęć, całkowicie odmiennym od kontekstu ich powstania i intencji autorów" (EMKA, Kołacz, Mejer 2017). Z kolei fotograf Rafał Wojczal mówił: „To nie są fotografie stockowe, którymi można ilustrować każdy temat, to są zdjęcia prasowe, każde $\mathrm{z}$ nich zostało opisane, znane są miejsca i daty. Nie zgadzam się, żeby służyły do takiego fotomontażu jako ilustracja do tematu oderwanego od kontekstu. Wykorzystywanie zdjęć w taki sposób uważam za obrzydliwą manipulację" (EMKA, Kołacz, Mejer 2017).

Konflikt wokół okładki funkcjonuje na - co najmniej - dwu poziomach: po pierwsze, widzimy, że fotografię traktuje się instrumentalnie, jest wykorzystywana bez uwzględnienia oryginalnego kontekstu obrazu. Potwierdzają to słowa jednej ze stron sporu, Tomasza Sakiewicza, który tłumaczył postępowanie gazety następująco: „zdjęcie to zdjęcie, nie robi się go w kontekście, lecz wyłącznie utrwala obraz" (EMKA, Kołacz, Mejer 2017). Po drugie,

16 Okładka dostępna pod: http://www.press.pl/tresc/49346,fotoreporterzy-oburzeni-wykorzystaniem-ich-zdjec-na-okladce-gp_ (dostęp 11.10.2017) 
pozbawienie zdjęć kontekstu ich wykonania niweluje oryginalne znaczenia, które obraz przenosi. O ile praktyka taka jest typowa w dyskursie artystycznym, to w obiegu medialnym (a zwłaszcza informacyjnym) nie powinna być stosowana. Przeciw nadużyciom tego rodzaju protestowała Azoulay. I chociaż możemy mówić, że manipulacja przekazem fotograficznym jest równie stara jak sama fotografia (Struk 2010), to współczesne możliwości obróbki cyfrowej sprawiają, że potrzebujemy obywatelskiej wyobraźnia, by do sytuacji takich jak opisywana wcześniej nie dopuszczać lub - jeśli się zdarzyły - by wizualne nadużycia rozpoznawać.

Czytelnik tego eseju może się poczuć rozczarowany, że nie opisuję $\mathrm{w}$ nim wielu fotografii i nie przywołuję najbardziej rozgrzewających opinię publiczną dyskusji o etyce fotoreporterów. Termin "fotografia uchodźców” funkcjonuje obecnie jako kategoria polityczna. Celem tekstu było przedstawienie sytuacji, w której fotografie stają się zakładnikami dyskursu politycznego - dlatego stają się „niewidzialne”. Fotografię można uczynić widzialną, poświęcając jej uwagę i za jej pomocą rozmyślając o ludziach, których przedstawia. Nie ma jednej drogi interpretacji fotografii, istnieją jednak podpowiedzi, na co - analizując fotografię - powinno się zwrócić uwagę. Wśród wielu metod badawczych Gillian Rose proponuje uwzględnienie trzech aspektów fotografii: technologicznego, kompozycyjnego i społecznego (Rose 1997, 14-15). Pierwszy uwzględnia konstrukcyjno-ekonomiczne warunki wykonywania obrazu (np. inaczej fotografował wojnę krymską Roger Fenton, który dysponował ciężkim aparatem na statywie z płytami szklanymi o małej czułości, a inaczej wojnę w Afganistanie pokazywał Tim Hetherington wyposażony w poręczną lustrzankę z szybkostrzelną migawką), drugi przypomina, że konwencje estetyczne są historycznie zmienne (np. nagrodzone na World Press Photo w 2016 roku zdjęcie Warrena Richardsona, pokazujące uchodźcę przekazującego dziecko przez płot z drutu kolczastego, jest lekko rozmazane, zrobione niemal przypadkiem, niepoprawne z perspektywy tego, czego uczymy się na kursach fotografii, a jednak zgodne ze współczesnym myśleniem o kompozycji obrazu). Z kolei aspekt społeczny odnosi się do pytań o to, kto i dlaczego zrobił dane zdjęcie. Inną ścieżkę interpretacyjną wskazuje Barthes'owskie napięcie między treściami społecznymi (studium) a prywatnym przeżyciem (punctum) (Barthes 1996). W tej filozoficznej propozycji ważne jest indywidualne, często intymne doświadczenie, wywołane przez jakiś element obrazu. Porusza ono naszą pamięć i napełnia neutralny dotąd zapis wizualny prywatnym znaczeniem.

Każdy z wybranych przez nas sposobów analizy będzie dobry, jeśli doprowadzi do zrozumienia relacji zachodzącej w sytuacji fotografowania. Dlatego też szczególnie interesująca wydaje mi się propozycja Azoulay. Autorka Obywatelskiej wyobraźni pisze o trzech spojrzeniach, które mogą pomóc w interpretacji fotografii. Są to: 1) spojrzenie orientujące (orienting gaze), za pomocą którego rozpoznajemy podstawowe informacje 
o sfotografowanych ludziach, 2) spojrzenie profesjonalne (professional gaze), dzięki któremu oceniamy kompozycję, światło, pozę modela i kojarzymy relacje międzyobrazowe, i wreszcie 3) spojrzenie obywatelskie, które łączy dwa powyższe i umożliwia odbiorcy rekonstrukcję sytuacji fotografowania. Azoulay podkreśla: „obywatelska intencja pozwala spektatorowi rozpoznać także obecność tych, których w kadrze nie widać", i dalej pisze: „wymaga wysiłku interpretacyjnego, połączenia faktów i pracy wyobraźni, ponieważ nic na fotografii nie jest dane z góry" (Azoulay 2012, 121). W fotografii nie chodzi zatem, by z gotowych scen tworzyć nowe, które miałyby ilustrować arbitralnie stawiane tezy, lecz o to, by poznawać, co właściwie sfotografowano.

Napisałam we wstępie, że w większości fotografie cierpienia innych, chociaż tak mocno wbijają się w naszą podświadomość, są dla nas niewidzialne. Teraz wiem, że „niewidzialne” znaczy dla mnie „niezrozumiane”. Obywatelska wyobraźnia, efekt prowadzenia starannej edukacji wizualnej, tę niewidzialność przezwycięża.

\section{Bibliografia:}

Azoulay Ariella, 2012, Civil Imagination. A Political Ontology of Photography, Londyn, Nowy Jork.

Barthes Roland, 1996, Światło obrazu. Uwagi o fotografii, Trznadel J. (przeł.), Warszawa.

Berger John, 1999, O patrzeniu, Sikora S. (przeł.), Warszawa

Berger John, Mohr Jean, 1982, Another Way of Telling, Nowy Jork.

Broomberg Adam, Chanarin Oliver, 2008, Unconcerned but not indifferent, „foto8 Magazine”, March, http://www.broombergchanarin.com/textunconcerned-but-not-indifferent/ (dostęp 11.10.2017).

Cartier-Bresson Henri, 2005, Decydujacy moment, Łyczywek K. (przeł.), „Format”, nr 46, s. 2-4.

Cieniek Rafał, 2016, Uchodźcy w obiektywie. Poruszajace zdjęcia z 2015 roku, „onet.pl”, http://wiadomosci.onet.pl/swiat/uchodzcy-w-obiektywieporuszajace-zdjecia-z-2015-roku/n7dymy, (dostęp 05.09.2017).

Czarnecki Maciej, 2014, To zdjęcie robi furorę $w$ sieci. Mówi więcej niż opasłe raporty, „Gazeta Wyborcza”, http://wyborcza.pl/1,76842,16863162,To zdjecie = robi_furore w_sieci_Mowi_wiecej_niz_opasle.html (dostęp 05.09.2017).

Didi-Huberman Georges, 2010, Obrazy mimo wszystko, Kubiak Ho-Chi M. (przeł.), Kraków.

Edwards Steve, 2014, Fotografia. Bardzo krótkie wprowadzenie, Zwierżdżyński M.K. (przeł.), Kraków.

EMKA, Kołacz Iga, Mejer Jakub, 2017, Fotoreporterzy oburzeni wykorzystaniem ich zdjęć na okładce „GP”, „Press”, http://www.press.pl/tresc/49346, fotoreporterzy-oburzeni-wykorzystaniem-ich-zdjec-na-okladce-gp_, (dostęp 05.09.2017).

Francuz Piotr, 2013, Imagia. W kierunku neurokognitywnej teorii obrazu, Lublin. 
Hall Stuart, 1997, Introduction, w: Hall S. (red.), Representation. Cultural Representations and Sygnifying Practices, Milton Keynes, s. 1-12.

Jenkins Henry, 2006, Kultura konwergencji. Zderzenie starych i nowych mediów, Bernatowicz M., Filiciak M. (przeł.), Warszawa.

Kimmelman Michael, 2001, Can Suffering be too Beautiful?, New York Times, 13 July http://www.nytimes.com/2001/07/13/arts/photography-review-cansuffering-be-too-beautiful.html (dostęp 20.10.2017)

Kopecka-Piech Katarzyna, 2015, Leksykon konwergencji mediów, Kraków.

Marinovich Greg, Silva João, 2012, Bractwo Bang Bang. Migawki z ukrytej wojny, Jagielski W. (przeł.), Kraków.

Miller Krzysztof, 2013, 13 wojen i jedna. Prawdziwa historia reportera wojennego, Kraków.

Miller Krzysztof, 2017, Fotografie, które nie zmieniły świata, Warszawa.

Mitchell William J.T., 2005, What Do Pictures Want? The Lives and Loves of Images, Chicago.

Petty Felix, 2016, Wstrzasajace zdjęcia nagrodzone World Press Photo, „i-D”, Śmiechowska P. (przeł.), https://i-d.vice.com/pl/article/43vpjn/wstrzasajacezdjecia-nagrodzone-world-press-photo (dostęp 05.09.2017).

Price Derrick, 1996, Surveyors and surveyed: photography out and about, w: Wells L. (red.), Photography: A Critical Introduction, London and New York, ss. 65-112.

Rose Gillian, 1997, An Introduction to the Interpretation of Visual Materials, London

Rostkowska Agnieszka, Jeśli to zdjęcie nie zmieni stosunku do uchodźców, to czy cokolwiek będzie w stanie go zmienić?, „Wyborcza”, http://wyborcza. pl/1,75399,18701523,jesli-to-zdjecie-nie-zmieni-stosunku-do-uchodzcow-czycokolwiek.html (dostęp 05.09.2017).

Sekula Allan, 2010, Społeczne użycia fotografii, Pijarski K. (przeł.), Warszawa.

Smith Helen, 2015, Shocking images of drowned Syrian boy show tragic plight of refugees, „The Guardian” 2.09.2015, https://www.theguardian.com/ world/2015/sep/02/shocking-image-of-drowned-syrian-boy-shows-tragicplight-of-refugees (dostęp 11.10.2017)

Sontag Susan, 2003, Regarding the Pain of Others, Londyn.

Sontag Susan, 2010, Widok cudzego cierpienia, Magala S. (przeł.), Kraków.

Struk Janina, 2007, Holokaust w fotografiach. Interpretacje dowodów, Warszawa.

Wischmann Lesley, 1987, Dying on the front page: Kent state and the Pulitzer Prize. Journal of Mass Media Ethics. 2, 2, 67-74, Jan. .

Wroe Nicolas, 2000, Man with the golden eye, „The Guardian”, https://www. theguardian.com/artanddesign/2000/jun/10/photography.art, (dostęp 05.09.2017).

Ziętkiewicz Marta, Biernacka Małgorzata, (red.), 2015, Miejsce fotografii $w$ badaniach humanistycznych, Warszawa. 


\section{O Autorce:}

Marianna Michałowska - dr hab. prof. UAM - pracuje w Instytucie Kulturoznawstwa Uniwersytetu im. Adama Mickiewicza w Poznaniu. Absolwentka UAM oraz Studium Fotografii Profesjonalnej ASP (obecnie Uniwersytet Artystyczny) w Poznaniu. Prowadzi badania nad sferą wizualną współczesnej kultury artystycznej (fotografia, studia miejskie). W tekstach krytycznych zajmuje się problematyką medialną. Autorka realizacji wykorzystujących fotografię i kuratorka wystaw. Publikuje w czasopismach naukowych i magazynach artystycznych. Redaktor naczelna kwartalnika „Kultura Współczesna”. Jest autorką książek: Niepewność przedstawienia. Od kamery obskury do współczesnej fotografii (2004), Obraz utajony. Szkice o fotografii i pamięci (2007), Foto-teksty. Zwiazki fotografii $z$ narracja (2012). 